\title{
Association between headache and tinnitus among medical students
}

\author{
Associação entre cefaleia e zumbido em acadêmicos de medicina \\ Deborah Ribeiro BESSA', Marianna Andrade de Almeida DUNKEL'1, Larissa Ribeiro BESSA', Luís Antônio \\ Bahiana CRUZ1', Katia de Miranda AVENA', Bruno Farias LESSA ${ }^{1}$
}

\begin{abstract}
Background: Headache is a very common complaint and it is increasingly prevalent among university students. Tinnitus consists of subjectively perceived sounds that occur in the absence of an external auditory signal. Presence of headache and tinnitus in association has implications for therapy and prognosis, because this describes the temporality of the symptoms. Recognition of the epidemiological profile of symptomatic students might contribute to interventions. Objective: To investigate the prevalence of the association between headache and tinnitus, and to describe the epidemiological profile of the study population and the chronological order of appearance of these symptoms. Methods: Cross-sectional, observational and analytical study on a sample representative of an academic center. Data referring to the epidemiological and clinical profile of headache and tinnitus among medical students were collected through an online questionnaire built using the Google Forms tool. Results: Out of the 234 participants, $26.1 \%$ reported having tinnitus and headache $(p<0.001)$. The participants with headache were more likely to be women $(p=0.045)$, white $(p=0.009)$ and $21-25$ years old $(p=0.356)$. Among right-sided, left-sided and non-unilateral headaches, tinnitus was present predominantly in the non-unilateral type, but without statistical significance. Regarding timing, $18.0 \%$ of the students said that tinnitus started before headache, $57.4 \%$ said that headache started before tinnitus and $24.6 \%$ said that they started simultaneously. Conclusions: An important association between headache and tinnitus regarding lateralization and temporality was demonstrated. Thus, these data match the presumption that headache and tinnitus have a physiopathological connection.
\end{abstract}

Keywords: Headache; Tinnitus; Students, Medical.

\begin{abstract}
RESUMO
Antecedentes: A cefaleia é uma queixa muito frequente e a prevalência em estudantes universitários vem sendo cada vez mais comum. Os zumbidos constituem percepções subjetivas de sons que acontecem na ausência de um sinal auditivo externo ou não. A correlação desses sintomas é importante para fins terapêuticos e prognóstico, pois descrever a temporalidade dos sintomas e conhecer o perfil epidemiológico dos estudantes sintomáticos pode contribuir com intervenções. Objetivo: Investigar a prevalência da relação da cefaleia e zumbido, descrever o perfil epidemiológico da população estudada e a ordem temporal do aparecimento desses dois sintomas. Métodos: Estudo de corte transversal, observacional e analítico representativo de um centro acadêmico. Foram coletados dados referentes ao perfil epidemiológico e clínico da cefaleia e zumbido entre acadêmicos de Medicina, por meio de um questionário online construído na ferramenta Google Forms. Resultados: Dos 234 participantes, 26,1\% relataram a presença de zumbido e cefaleia. Os participantes com cefaleia apresentaram maior probabilidade de serem mulheres, da raça branca e ter entre 21-25 anos. Dentre as cefaleias sem unilateralidade, as localizadas à direita e as localizadas à esquerda, o zumbido predominou no tipo sem unilateralidade, entretanto sem significância estatística. Observou-se que $18,0 \%$ dos acadêmicos relataram o início do zumbido antes da cefaleia, 57,4\% relataram o início da cefaleia antes do zumbido, e $24,6 \%$ início simultâneo. Conclusões: Foi demonstrada uma importante relação entre cefaleia e zumbido acerca da lateralidade e temporalidade. Assim, esses dados se encaixam na presunção de que a cefaleia e o zumbido possuem uma ligação fisiopatológica.
\end{abstract}

Palavras-chave: Cefaleia; Zumbido; Estudantes de Medicina.

\section{INTRODUCTION}

Headache is a very frequent complaint and is associated with the quality of life of patients who look for consultations in healthcare units. According to the Brazilian Headache Society, this is the seventh most disabling symptom in the world, reaching around 149 million Brazilians ${ }^{1}$.

Headaches can be classified as primary or secondary ${ }^{2}$. Primary headaches are those that cannot be attributed to a specific cause, and include headache types such as migraine,

${ }^{1}$ Centro Universitário UniFTC, Salvador BA, Brazil.

DRB (iD https://orcid.org/0000-0003-3139-0518; MAAD (iD https://orcid.org/0000-0003-3759-7931; LRB (D) https://orcid.org/0000-0001-9839-0067;

LABC (iD) https://orcid.org/0000-0003-1859-3011; KMA(D) https://orcid.org/0000-0002-2179-3893; BFL (D) https://orcid.org/0000-0001-9789-372X

Correspondence: Bruno Farias Lessa; Email: brunolessaotorrino@gmail.com.

Conflict of interest: There is no conflict of interest to declare.

Authors' contributions: DRB, MAAD: conception, design, materials, data collection, analysis and interpretation, literature review, writing and critical review; LRB, LABC: analysis and interpretation, literature review, writing and critical review; KMA, BFL: design, supervision, analysis and interpretation, writing and critical review.

Received on January 18, 2021; Received in its final form on February 04, 2021; Accepted on February 24, 2021.

(cc) BY 
tension-type headache (TTH) or trigeminal autonomic cephalalgias (TACs) ${ }^{3}$. The most common among those is $\mathrm{TTH}^{4}$. On the other hand, secondary headaches are associated with symptoms of an underlying disease, which may be neurological or systemic ${ }^{5}$.

Over recent times, the presence of headaches in university students has become more common. It can be supposed that there is an association between the presence of headaches and factors such as overload, stress, irritability, insomnia and depression among students. It is important to highlight that headaches might have a negative influence on family relationships and on individuals' social behavior. They may cause discontentment in the lives of the individuals affected, regarding academic organization and planning ${ }^{6}$.

Another relevant symptom is the buzzing sound known as tinnitus, which has been described as subjectively perceived sounds that occur in the absence of an external auditory signal. It has been shown that the prevalence of this symptom increases with age, but there is still a large proportion of occurrences among young adults ${ }^{7}$. Given that tinnitus is considered to be a symptom, it might have several causes, among which the most common is hearing loss 8 . There are also other less common causes, which may include the following: otoscopic causes, such as sudden loss of hearing; hearing loss induced by noise; neurological causes (cervical trauma, multiple sclerosis or acoustic neurinoma); metabolic causes (diabetes, hypercholesterolemia or thyroid diseases); infectious causes (otitis media, meningitis or syphilis); drug-induced causes (salicylates, aminoglycosides, anti-inflammatory drugs, diuretics or chemotherapeutics); or odontological causes (temporomandibular dysfunction) $)^{8,9}$.

The Tinnitus Handicap Inventory (THI) is considered to be the ideal method for evaluating the level of severity of tinnitus. Recent studies have also demonstrated that visual analogue scales (VAS) present a good association with $\mathrm{THI}^{10}$.

In a study conducted between 2003 and 2011, at the Interdisciplinary Tinnitus Center of Regensburg University, headache and tinnitus occurring in association was demonstrated to be highly meaningful according to the laterality of the symptoms. In that study, it was demonstrated that $54.9 \%$ of the subjects reported that their headache preceded the onset of tinnitus, while a small proportion (10.4\%) reported simultaneous onset of the symptoms ${ }^{11}$.

Therefore, presence of an association of headache and tinnitus is extremely important with regard to therapy and prognosis, given that this shows a chronological order of symptoms. Knowledge of the epidemiological profile of symptomatic students can contribute to interventions that can prevent progression of clinical cases.

Thus, the aims of the present study were to investigate the prevalence of the association between headache and tinnitus and to describe the epidemiological profile of the study population and the chronological order of the appearance of these two symptoms.

\section{METHODS}

This was a cross-sectional, observational and analytical study, on a sample representative of a university center located in the city of Salvador, Bahia, Brazil.

The sample size was estimated using the Comentto sample calculator. A total population of 1,630 medical students from this educational institution was considered, with homogenous distribution, a confidence level of $95 \%$ and a margin of error of $5 \%$. Thus, it was estimated that, through spontaneous demand, data on at least 214 students would need to be collected for this study. Overall, 234 medical students who filled out the initial questionnaire were included in the study. The inclusion criteria were age between 18 and 65 years, and active registration as a medical student on the Salvador campus. Students who did not agree to the free and informed consent statement were excluded.

Headache and tinnitus data were collected between August and September 2020, through application of a standardized online questionnaire containing 35 objective questions about the epidemiological profile and clinical characteristics of headache and tinnitus among medical students at this university center. The questionnaire was distributed through an online platform for virtual communication through instant messages. The form was sent out through a link generated through the Google Forms tool. Medical students who were interested in participating needed to agree to the free and informed consent statement in order to access the questionnaire.

The following variables were evaluated: sex, age, race, clinical characteristics of headache and tinnitus, temporal association between headache and tinnitus, factors that worsened both symptoms, location of the headache and its characteristics, laterality and characteristics of tinnitus.

Headaches were classified using the International Classification of Headache Disorders ${ }^{12}$. Tinnitus was classified by applying the criterion of the degree of discomfort, using a VAS.

Categorical variables were presented as absolute numbers (n) and relative frequencies (\%), and medians were used for quantitative variables. The chi-square test was used to compare frequencies among the study groups. P-values below 0.05 or $5 \%$ were considered statistically significant. The data collected were tabulated using Microsoft Excel 2016 (Microsoft Corporation, Redmond, Washington, USA). Statistical analyses were performed using the GraphPad 7 statistical software (GraphPad Software Inc., San Diego, California, USA).

This study respected the definitions proposed through the Declaration of Helsinki and was approved by our institution's Research Ethics Committee for Human Beings, in accordance with the ethical precepts of Resolution 466/2012 of the National Health Council. The data were collected under a guarantee of confidentiality, which ensured privacy and anonymity for the subjects regarding the confidential data involved in the research, without any situation that might cause any type of biological, physical and/or psychological harm. 


\section{RESULTS}

Overall, out of the 234 medical students included in the study, 203 (86.8\%) reported having had presence of headaches. Among these individuals, 62 (26.5\%) reported having had nonmigraine headaches, $99(42.3 \%)$ reported migraine without aura and 42 (17.9\%) reported migraine with aura.

Among the 203 individuals with headaches, 159 (78.3\%) were women and $44(21.7 \%)$ were men (Table 1$)$. These proportions are similar to what is seen in the overall population (respectively $76.1 \%$ and $23.9 \%$ ). However, the proportions according to sex among the students who did not present headaches were different, with 19 women (61.3\%) and 12 men (38.7\%) in this subpopulation. Therefore, comparison of the groups of students with and without headaches, taking sex into consideration, showed a statistical difference $(p=0.045$; Table 1$)$.

The most prevalent age group was that of individuals aged 21 to 25 years. However, the prevalence of headache could not be distinguished according to age $(p=0.356$; Table 1$)$.

With regard to race, although white and brown individuals showed higher prevalence in this sample, accounting for $47.4 \%$ and $43.6 \%$ of the participants, the distribution and characteristics of the population did not fit within the validity criteria of the chi-square test ( $p=0.009$; Table 1$)$.

Overall, headache was predominantly presented by female and white individuals, with ages between 21 and 25 years in the population studied, in absolute numbers. Furthermore, out of the 203 subjects who presented headache, 61 individuals
(26.1\%) reported having overlapping occurrences of tinnitus and headache $(\mathrm{p}<0.001$; Table 1$)$.

Among the 61 individuals who presented both headache and tinnitus, 21 (34.4\%) presented non-migraine headaches, while 40 presented migraine with aura $(n=19 ; 31.2 \%)$ or without aura $(n=21 ; 34.4 \%)$.

Table 2 details the epidemiological and clinical data with regard to these classifications. Considering these distinct types of presentations, neither sex, age, race, course year, most affected period and family history, nor number of episodes per month, could distinguish individuals in these groups. With regard to the degree of discomfort caused by tinnitus, on a scale that ranged from 1 (minimum) to 10 (maximum), 4 was the median score found among the students' responses.

With regard to the laterality of both tinnitus and headaches, although individuals predominantly presented both conditions without laterality, these characteristics could not distinguish whether those with laterality of headache would present unilateral tinnitus or vice versa $(p=0.277$; Figure 1$)$. However, as illustrated in Figure 2, there was a statistically significant difference in the proportions of tinnitus presentation, with regard to the type of headache reported by the study population. Students with tinnitus presented significantly less migraine without aura than migraine with aura, while students without tinnitus predominantly presented migraine without aura ( $\mathrm{p}=0.013$; Figure 2).

Furthermore, the students were also asked about the time of onset of tinnitus and headache. Overall, 11 students (18\%)

Table 1. Sociodemographic characteristics of medical students, considering the presence or absence of headache.

\begin{tabular}{|c|c|c|c|}
\hline \multirow[b]{2}{*}{ Variable } & \multicolumn{2}{|c|}{ Headache } & \multirow[b]{2}{*}{$p$-value* } \\
\hline & $\begin{array}{l}\text { Without } \\
(n=31)\end{array}$ & $\begin{array}{c}\text { With } \\
(n=203)\end{array}$ & \\
\hline \multicolumn{4}{|l|}{ Sex, n (\%) } \\
\hline Female & 19 (61.3) & 159 (78.3) & 0.045 \\
\hline Male & 12 (38.7) & $44(21.7)$ & \\
\hline \multicolumn{4}{|l|}{ Age, n (\%) } \\
\hline $18-20$ years & $3(9.7)$ & $43(21.2)$ & 0.356 \\
\hline 21-25 years & $21(67.7)$ & $130(64.0)$ & \\
\hline $26-30$ years & $4(12.9)$ & $14(6.9)$ & \\
\hline$>30$ years & $3(9.7)$ & $16(7.9)$ & \\
\hline \multicolumn{4}{|l|}{ Race, n (\%) } \\
\hline White & 19 (61.3) & $92(45.3)$ & $0.009^{+}$ \\
\hline Brown & $11(35.5)$ & $91(44.8)$ & \\
\hline Black & $0(0)$ & $20(9.9)$ & \\
\hline Other & $1(3.2)$ & $0(0)$ & \\
\hline \multicolumn{4}{|c|}{ Tinnitus, n (\%) } \\
\hline Yes & $0(0)$ & $61(30.1)$ & $<0.001$ \\
\hline No & $31(100)$ & $142(69.9)$ & \\
\hline
\end{tabular}

$\mathrm{n}$ : absolute frequency; \%: relative frequency; ${ }^{\top}$ The variables were analyzed using either the Fisher exact test or the chi-square test, as appropriate. ${ }^{\dagger}$ In the chi-square test, all expected values need to be greater than 1, and at least $20 \%$ of these values ought to be higher than 5 . Considering that neither of these conditions was met, the $p$-values for the test on this variable do not present validity. 
Table 2. Sociodemographic characteristics of medical students, considering the type of headache and tinnitus.

\begin{tabular}{|c|c|c|c|c|}
\hline \multirow{2}{*}{ Variable } & \multicolumn{2}{|c|}{ Migraine } & \multirow{2}{*}{$\begin{array}{l}\text { Non migraine } \\
\quad(n=21)\end{array}$} & \multirow{2}{*}{$p$-value* } \\
\hline & With aura $(n=19)$ & Without aura $(n=21)$ & & \\
\hline \multicolumn{5}{|l|}{ Sex, n (\%) } \\
\hline Female & $16(84.2)$ & $16(76.2)$ & $15(71.4)$ & 0.626 \\
\hline Male & $3(15.8)$ & $5(23.8)$ & $6(28.6)$ & \\
\hline \multicolumn{5}{|l|}{ Age, n (\%) } \\
\hline $18-20$ years & $7(36.8)$ & $2(9.5)$ & $4(19.1)$ & $0.521^{\dagger}$ \\
\hline 21-25 years & $10(52.6)$ & $16(76.2)$ & $13(61.9)$ & \\
\hline $26-30$ years & $1(5.3)$ & $1(4.8)$ & $2(9.5)$ & \\
\hline$>30$ years & $1(5.3)$ & $2(9.5)$ & $2(9.5)$ & \\
\hline \multicolumn{5}{|l|}{ Race, n (\%) } \\
\hline White & $12(63 ., 2)$ & $11(52.4)$ & $10(47.6)$ & 0.156 \\
\hline Brown & $6(31.6)$ & $4(19.1)$ & $9(42.9)$ & \\
\hline Black & $1(5.3)$ & $6(28.6)$ & $2(9.5)$ & \\
\hline Other & - & - & - & \\
\hline \multicolumn{5}{|c|}{ Year of course, $n(\%)$} \\
\hline $1-2$ & $6(31.6)$ & $7(33.3)$ & $2(9.5)$ & 0.163 \\
\hline $3-4$ & $12(63.2)$ & $10(47.6)$ & $13(61.9)$ & \\
\hline $5-6$ & $1(5.3)$ & $4(19.1)$ & $6(28.6)$ & \\
\hline \multicolumn{5}{|c|}{ Period most affected, n (\%) } \\
\hline Classes & $9(47.4)$ & $10(47.6)$ & $8(38.1)$ & 0.781 \\
\hline Tests & $10(52.5)$ & $11(52.4)$ & $13(61.9)$ & \\
\hline Vacations & - & - & - & \\
\hline \multicolumn{5}{|c|}{ Family history, n (\%) } \\
\hline Yes & $13(68.4)$ & $13(61.9)$ & $12(57.1)$ & 0.763 \\
\hline No & $6(31.6)$ & $8(38.1)$ & $9(42.9)$ & \\
\hline \multicolumn{5}{|c|}{ Frequency in one month, $\mathrm{n}(\%)$} \\
\hline 4 times & $10(52.6)$ & $10(47.6)$ & $17(81.0)$ & 0.1133 \\
\hline 8 times & $2(10.5)$ & $5(23.8)$ & $2(9.5)$ & \\
\hline 12 times & $6(31.6)$ & $3(14.3)$ & $2(9.5)$ & \\
\hline 16 times or more & $1(5.3)$ & $3(14.3)$ & $0(0)$ & \\
\hline
\end{tabular}

n: absolute frequency: \%: relative frequency: *The variables were analyzed using either the Fisher exact test or the chi-square test, as appropriate. ${ }^{\dagger} \mid \mathrm{n}$ the chi-square test, all expected values need to be greater than 1, and at least $20 \%$ of these values ought to be higher than 5 . Considering that neither of these conditions was met, the $p$-values for the test on this variable do not present validity.

$\mathrm{p}=0.277$

$\square$ Tinnitus without unilaterality tinnitus

एus Left side tinnitus

Right side tinnitus

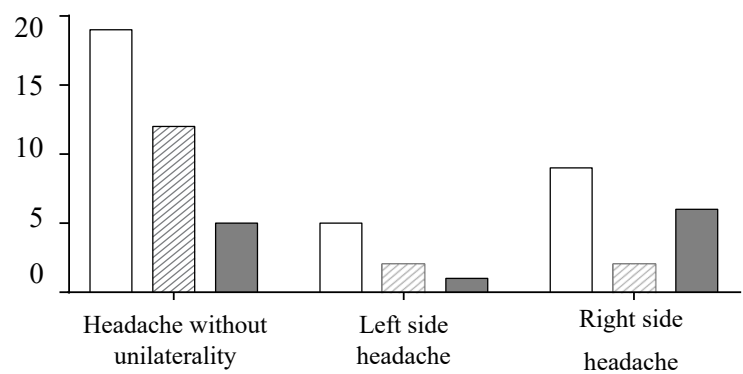

Figure 1. Association of headache and tinnitus among medical students, considering the location of the laterality. Salvador, Bahia, Brazil, 2020. Distribution of students according to laterality of headache and tinnitus. Data were analyzed using the chi-square test.

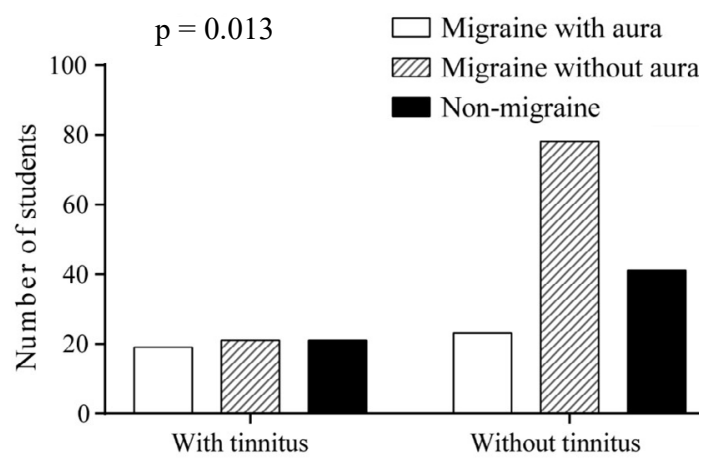

Figure 2. Presentation of tinnitus according to the type of headache among medical students. Salvador, Bahia, Brazil, 2020. Distribution of students according to the presence of tinnitus per type of headache presentation. Data were analyzed using the chi-square test. 
reported that the onset of tinnitus was before the headache, while 35 reported that the onset of the headache was before the tinnitus (57.4\%) and 15 reported simultaneous onset of both symptoms (24.6\%). Moreover, 46 students (75.4\%) stated that the onset of the second symptom did not influence the intensity of the first, while $15(24.6 \%)$ reported worsening of the first symptom. No students reported that the onset of the second symptom attenuated the first. In addition, 15 students (24.6\%) reported that worse intensity of tinnitus was associated with aggravation of headache and vice versa, while 46 students $(75.4 \%)$ said that there was no such association. No students reported that increased intensity of one symptom actually attenuated the other.

\section{DISCUSSION}

This study demonstrated that there was a strong association between headache and tinnitus among medical students at a private institution in the city of Salvador, Bahia. Furthermore, the frequency of the presentation of tinnitus in individuals with different types of headache (migraine with or without aura, and non-migraine) was analyzed in the study population. We did not find any assessment of this perspective in any other published studies of this kind. The students predominantly stated that tinnitus or headache did not influence the intensity of the other symptom, and a minority reported that when the intensity of tinnitus was stronger, the headaches were worse.

In this context, a high number of students described occurrences of headaches, but in a similar proportion to that reported for the general population, which is around $90 \%$ overall $^{13-16}$. There was high prevalence of headache among women, a result that has also been found in other studies in Brazil ${ }^{15,16}$ and elsewhere $^{17,18}$. Although individuals who self-declared as white had higher prevalence of headache, which is consistent with a study by Mildner et $a l .{ }^{19}$, the low numbers of individuals in other distributions with regard to race weakens this finding presented here. In addition, age could not distinguish between students who reported having headache and those who did not, in the study population. Data regarding the age profile of headaches among students remains scarce.

A few studies have covered the subject of the association between headache and tinnitus ${ }^{11,20-22}$. Although the population of the present study was composed primarily of young adults and all of the individuals who reported that they did not have headaches also said that they did not have tinnitus, around 30\% of the subjects who presented headache also reported occurrences of tinnitus $(\mathrm{p}<0.001$; Table 1$)$. This finding indicates that headache was a factor directly associated with the presentation of tinnitus in the population studied. In absolute numbers, the demographic characteristics most often presented among individuals with headache and tinnitus were female, age 21-25 years and white race. These results were consistent with what has been reported in other studies ${ }^{20,22}$.
The students who reported having migraine were predominantly in the third and fourth academic years, in absolute terms. Although this distribution did not present any statistically significant difference, we believe that this an important finding. It might be explained by the fact that at this stage of the medical course, students are faced with the reality that they need to prepare themselves for professional performance, with emphasis on care and assistance to people and on health promotion, which can generate stress ${ }^{23}$. Nonetheless, other studies have demonstrated higher prevalence in the fifth and sixth years of the course ${ }^{24,25}$. Moreover, Carneiro et al. ${ }^{16}$ reported that students have more migraine crisis during the exams period, and that there was higher prevalence among those with a positive family history, which were results found in this study in absolute frequencies. In addition, no significant difference was found with regard to frequency of headache or migraine episodes among subjects with tinnitus.

In a study conducted in France, Henry et al. ${ }^{26}$ demonstrated lower frequencies of headache: $17 \%$ of their subjects had headaches less than once a month, $32 \%$ had them once a month, $40 \%$ had them two to four times a month and $10 \%$ had them more than once a week. Additionally, those medical students reported having mild discomfort in assessing their intensity of tinnitus overall, although the absolute numbers registered were lower than what had been reported in the literature ${ }^{27}$.

With regard to laterality of headache and tinnitus, the present study did not find any significant association between the symptoms. In contrast, Langguth et al. ${ }^{11}$ reported a respective association regarding the laterality of the symptoms: in other words, in cases of laterality of tinnitus, the headache would be preponderantly on the same side.

In addition, with regard to temporality and influence between the symptoms, our results were antagonistic to what had previously been reported ${ }^{11}$. In the present study, it was demonstrated that the majority of the students presented headache before tinnitus, in absolute terms. This may be explained by the fact that development of tinnitus is facilitated through the sensitization of the trigeminal system that is caused by unilateral headache ${ }^{28}$. Nevertheless, a similar mechanism may explain occurrences of tinnitus preceding headache ${ }^{28}$. Therefore, the data presented here reinforces the hypothesis that headache and tinnitus are connected by common physiopathological mechanisms.

Furthermore, with regard to influence and aggravation between the symptoms, the students predominantly responded that the onset of the second symptom did not influence the intensity of the first symptom. They also reported that worsening or alleviation of the intensity of one symptom did not interfere with the intensity of the other symptom. Thus, it can be seen that there is a need for further studies to explain whether the symptoms are related with regard to severity or whether the interrelationship between them causes severe tinnitus, which could help in future therapeutic measures. 
From a physiopathological perspective, the association between headache and tinnitus is not currently known. However, some studies have shown similar mechanisms of specific alterations in thalamocortical activity between the two systems, which may generate a significant relationship ${ }^{28-32}$. Moreover, there is agreement in the literature that stress is a triggering factor for both headache ${ }^{33}$ and tinnitus ${ }^{34}$. Therefore, this might be an explanation for the larger number of students who reported that examinations and class periods were the worst times for the symptoms, given that these are considered to be the most stressful times ${ }^{35}$. Increased caffeine ${ }^{36}$ and carbohydrate ${ }^{37}$ consumption, prolonged fasting periods ${ }^{37}$, sleep disorders ${ }^{38}$ and sedentary lifestyl ${ }^{39}$ could also explain why students might be more susceptible to presentation of these symptoms at these times. Further investigations are still necessary in order to assess these hypotheses. In addition, with regard to laterality and the matter of occurrence of both symptoms over time, it was not possible to conclude that a physiopathological relationship would define the explanation.

There were some limitations to this study. All the headache diagnoses were based on the ICHD-3-2018. However, some points may have generated incorrect classification bias. As this was an online questionnaire, there was the possibility of subjective interpretation of the questions about headache and tinnitus, which might have increased the rate of false-positive results. Another point is that there may have been some unmeasured variables, due to the need for a headache diary in more partial diagnoses. Other unevaluated variables would include medication use, factors that improve or worsen the headache, pre-existing conditions, previous diagnoses of headache and non-application of the THI questionnaire in its entirety. These possible variables may have confounded the results from the study. Therefore, the data from the present study serve as a preliminary assessment of the problem, but new studies are needed for a better evaluation.

In conclusion, an important association between headache and tinnitus, regarding the laterality and temporality of these symptoms, was demonstrated. Migraine without aura was the most prevalent type of headache among the students without tinnitus. Among those with tinnitus, there was similar prevalence between migraine with or without aura and nonmigraine headache. Therefore, the data presented here are in line with the presumption that headache and tinnitus have a physiopathological connection.

\section{REFERENCES}

1. Faro P. Dia nacional do combate à cefaleia [Internet]. Sociedade Brasileira de Cefaleia. 2017 [cited 2020 May 1]. Available from: https://sbcefaleia.com.br/noticias. php?id=321

2. Gherpelli JLD. Tratamento das cefaléias. J Pediatr (Rio J). 2002 Jul;78 Suppl 1:S3-8. https://doi.org/10.2223/JPED.844

3. Pessigatti BP, Rodrigues APC, Aguiar PV, Dias FM. Health biopsychosocial aspects of students and collaborators of a higher education institution suffering from headache. Br J P. 2020 JanMar;3(1):19-24. https://doi.org/10.5935/2595-0118.20200005

4. Sobieski M, Korzeniewska A. Tension-type headache-most prevalent, still unknown. World Sci News. 2019;135(9):14-31.

5. Speciali JG, Kowacs F, Jurno ME, Bruscky IS, Carvalho JJC, Goreth F, et al. Protocolo nacional para diagnóstico e manejo das cefaleias nas unidades de urgência do Brasil. Academia Brasileira de Neurologia; Departamento Científico de Cefaleia da Sociedade Brasileira de Cefaleia; 2018 [cited 2020 May 1]. 11 p. Available from: https:// sbcefaleia.com.br/images/protocolo cefaleia urgencia.pdf

6. Johansson A-M, Vikingsson H, Varkey E. The physiotherapist, an untapped resource for headaches: a survey of university students. Eur J Physiother. 2017 Jul;20(1):45-50. https://doi.org/10.1080/2167 9169.2017.1352023

7. Park B, Choi HG, Lee H-J, An S-Y, Kim SW, Lee JS, et al. Analysis of the prevalence of and risk factors for tinnitus in a young population. Otol Neurotol. 2014 Aug;35(7):1218-22. https://doi.org/10.1097/ MAO.0000000000000472

8. Manche SK, Madhavi J, Meganadh KR, Jyothy A. Association of tinnitus and hearing loss in otological disorders: a decadelong epidemiological study in a South Indian population. Braz J Otorhinolaryngol. 2016 Nov-Dec;82(6):643-9. https://doi. org/10.1016/j.bjorl.2015.11.007

9. Lockwood AH, Salvi RJ, Burkard RF. Tinnitus. N Engl J Med. 2002 Sep 19;347(12):904-10. https://doi.org/10.1056/NEJMra013395

10. Figueiredo RR, Azevedo AA, Oliveira PM. Análise da correlação entre a escala visual-análoga e o Tinnitus Handicap Inventory na avaliação de pacientes com zumbido. Rev Bras Otorrinolaringol. 2009 JanFeb;75(1):76-9.

11. Langguth B, Hund V, Busch V, Jurgens TP, Lainez JM, Landgrebe M, et al. Tinnitus and headache. Biomed Res Int. 2015;2015:797416. https://doi.org/10.1155/2015/797416

12. Comitê de Classificação das Cefaleias da Sociedade Internacional de Cefaleia. The International Classification of Headache Disorders (ICHD-3). 3rd ed. São Paulo: Omnifarma Editora; 2018.78p.

13. Ferri-de-Barros JE, de Alencar MJ, Berchielli LF, Castelhano Junior LC. Cefaléia em estudantes de medicina e psicologia. Arq Neuropsiquiatr. 2011 Jun;69(3):502-8. https://doi.org/10.1590/ S0004-282X2011000400018

14. Andrade AFB, Back DFFT, Rocha EF, Duarte GF, Batista ICB, Jurno ME, et al. Prevalência e fatores associados à enxaqueca nos estudantes da Faculdade de Medicina de Barbacena, MG - Brasil. Rev Med Minas Gerais. 2011;21(1):25-31.

15. Lima AS, Araújo RC, Gomes MRA, Almeida LR, Souza GFF, Cunha SB, et al. Prevalência de cefaleia e sua interferência nas atividades de vida diária em adolescentes escolares do sexo feminino. Rev Paul Pediatr. 2014 Jun;32(2):256-61. https://doi.org/10.1590/01030582201432212113

16. Carneiro AF, Cavalcante Neto PG, Ferreira JFIS, Garcia BF, Silva FDAC, Leal PRL. A prevalência de cefaleia e fatores psicossociais associados em estudantes de medicina no Ceará. Rev Med (São Paulo). 2019 May-Jun;98(3):168-79. https://doi.org/10.11606/ issn.1679-9836.v98i3p168-179

17. Hoover E. An analysis of the Association of American Medical Colleges' review of minorities in medical education. J Natl Med Assoc. 2005 Sep;97(9):1240-56.

18. Dhalla IA, Kwong JC, Streiner DL, Baddour RE, Waddell AE, Johnson IL. Characteristics of first-year students in Canadian medical schools. CMAJ. 2002 Apr 16;166(8):1029-35.

19. Mildner NM, Gobbato CZ, Panatto APR, Madeira K, Rosa MI, Simões PWTA. Características da cefaléia do tipo migrânea em pacientes 
atendidos no ambulatório médico da Universidade do Extremo Sul Catarinense no período de 2004 a 2009. Arq Catarin Med. 2012;41(4):57-62.

20. Guichard E, Montagni I, Tzourio C, Kurth T. Association between Headaches and Tinnitus in young adults: cross-sectional study. Headache. 2016 Jun;56(6):987-94. https://doi.org/10.1111/ head.12845

21. Lindberg P, Lyttkens L, Melin L, Scott B. Tinnitus-incidence and Handicap. Scand Audiol. 1984;13(4):287-91. https://doi. org/10.3109/01050398409042138

22. Lugo A, Edvall NK, Lazar A, Mehraei G, Lopez-Escamez J-A, Bulla J, et al. Relationship between headaches and tinnitus in a Swedish study. Sci Rep. 2020 May 22;10(1):8494. https://doi.org/10.1038/s41598020-65395-1

23. Dini PS, Batista NA. Graduação e prática médica: expectativas e concepções de estudantes de medicina do $1^{\circ}$ ao $6^{\circ}$ ano. Rev Bras Educ Med. 2004 Sep-Dec;28(3):198-203. https://doi. org/10.1590/1981-5271v28.3-026

24. Alwahbi MK, Alamri MM, Alammar AM, Alanazi AM, Alotaibi AG, Alharbi SK, et al. Prevalence of migraine among medical students of King Saud Bin Abdulaziz University for Health Sciences. Int J Sci Res. 2017 Feb;6(2):894-8.

25. Desouky DE, Zaid HA, Taha AA. Migraine, tension-type headache, and depression among Saudi female students in Taif University. J Egypt Public Heal Assoc. 2019 Jan 29;94(1):7. https://doi.org/10.1186/ s42506-019-0008-7

26. Henry P, Duru G, Chazot G, Dartigues JF. La migraine en France. Paris: John Libbey Eurotext; 1993. 118p.

27. Guimarães AC, de Carvalho GM, Voltolini MMFD, Zappelini CEM, Mezzalira R, Stoler G, et al. Estudo da relação entre o grau de incômodo de pacientes com zumbido e a presença de hiperacusia. Braz J Otorhinolaryngol. 2014 Jan-Feb;80(1):24-8. https://doi. org/10.5935/1808-8694.20140007

28. Llinás RR, Ribary U, Jeanmonod D, Kronberg E, Mitra PP. Thalamocortical dysrhythmia: a neurological and neuropsychiatric syndrome characterized by magnetoencephalography. Proc Natl Acad Sci U S A. 1999 Dec 21;96(26):15222-7. https://doi.org/10.1073/ pnas.96.26.15222

29. Moazami-Goudarzi M, Michels L, Weisz N, Jeanmonod D. Temporoinsular enhancement of EEG low and high frequencies in patients with chronic tinnitus. QEEG study of chronic tinnitus patients. BMC Neurosci. 2010 Mar 24;11(1):40. https://doi.org/10.1186/1471-2202$11-40$
30. De Tommaso M, Ambrosini A, Brighina F, Coppola G, Perrotta A, Pierelli F, et al. Altered processing of sensory stimuli in patients with migraine. Nat Rev Neurol. 2014 Mar;10(3):144-55. https://doi. org/10.1038/nrneurol.2014.14

31. De Ridder D, Vanneste S, Langguth B, Llinas R. Thalamocortical dysrhythmia: a theoretical update in tinnitus. Front Neurol. $2015 \mathrm{Jun}$ 9;6(4):124. https://doi.org/10.3389/fneur.2015.00124

32. Schmidt S, Naranjo JR, Brenneisen C, Gundlach J, Schultz C, Kaube H, et al. Pain ratings, psychological functioning and quantitative EEG in a controlled study of chronic back pain patients. PLoS One. $2012 \mathrm{Mar}$ 14;7(3):e31138. https://doi.org/10.1371/journal.pone.0031138

33. Santos R, Rêgo RCS, Santos VLB, Prado MR. Prevalência de cefaleia e seus impactos em estudantes de medicina em uma universidade pública. Rev Bras Neurol. 2019 Jul-Sep;55(3):5-8.

34. Rodrigues OMPR, Viana NPM, Palamin MEG, Calais S. Estresse e zumbido: o relaxamento como uma possibilidade de intervenção. Psicol Teor e Prática. 2014;16(1):43-56. https://doi. org/10.15348/1980-6906/psicologia.v16n1p43-56.

35. Lima RL, Soares MEC, Prado SN, Albuquerque GSC. Estresse do estudante de medicina e rendimento acadêmico. Rev Bras Educ Med. 2016 Oct-Dec;40(4):678-84. https://doi.org/10.1590/1981$52712015 v 40 n 4 e 01532015$

36. Morgan HL, Petry AF, Licks PAK, Ballester AO, Teixeira KN, Dumith SC. Consumo de estimulantes cerebrais por estudantes de medicina de uma universidade do extremo sul do Brasil: prevalência, motivação e efeitos percebidos. Rev Bras Educ Med. 2017 Jan-Mar;41(1):102-9. https://doi.org/10.1590/1981-52712015v41n1rb20160035

37. Marcondelli P, Costa THM, Schmitz BAS. Nivel de atividade física e hábitos alimentares de universitários do 3 ao 5 semestres da área de saúde. Rev Nutr. 2008 Jan-Feb;21(1):39-47. https://doi.org/10.1590/ S1415-52732008000100005

38. Castilho CP, de Limas LMD, Monteiro ML, da Silva PHMN, Bueno H, Fari TA. A privação de sono nos alunos da área de saúde em atendimento nas Unidades Básicas de Saúde e suas consequências. Rev Med (São Paulo). 2015 Apr-Jun;94(2):113-9. https://doi. org/10.11606/issn.1679-9836.v.94i2p113-119

39. de Castro Júnior EF, Barreto LA, Oliveira JAA, Almeida PC, Leite JAD. Avaliação do nível de atividade física e fatores associados em estudantes de medicina de Fortaleza-CE. Rev Bras Ciênc Esporte. 2012 Dec;34(4):955-67. https://doi.org/10.1590/S010132892012000400011 